\title{
Willem Witteveen, De wet als kunstwerk: Een andere filosofie van het recht. Hoe de filosofen onze wetgevers de maat nemen
}

\author{
Wouter de Been
}

Willem Witteveen, De wet als kunstwerk: Een andere filosofie van het recht. Hoe de filosofen onze wetgevers de maat nemen, Boom, Amsterdam (2014)

Willem Witteveen voltooide De wet als kunstwerk vlak voor hij in 2014 in vlucht MH17 de dood vond. De twee ondertitels, Een andere filosofie van het recht / Hoe de filosofen onze wetgevers de maat nemen, onderstrepen meteen dat we hier met een andersoortig boek te maken hebben in het rechtstheoretische genre. Witteveen stelt een rechtstheorie voor die het recht beschouwt als een kunstwerk. Hij combineert zijn rechtstheoretische overpeinzingen, die het grootste deel van het boek uitmaken, met beschouwingen over de literatuur, met eigen poëzie, met een kort toneelwerk, en zelfs met eigen 'collages en miniaturen' - een toevoeging die Uitgeverij Boom genereus heeft mogelijk gemaakt voor deze postume publicatie. Je zou De wet als kunstwerk daarmee zelf als een soort Gesamtkunstwerk kunnen zien. Bij Gesamtkunstwerk moet dan niet gedacht worden aan een symbiotische en minutieus uitgedachte creatie zoals een opera van Wagner opgevoerd in het speciaal daarvoor ontworpen Bayreuther Festspielhaus. Bij Witteveen gaat het veeleer om een speelse samenhang van elementen zoals in een collage, of in een voorstelling totaaltheater. Willem Witteveen was geen systeembouwer, geen Hegel of Habermas, maar een bricoleur, iemand die op een speelse manier nieuwe, creatieve samenhangen creëerde uit de diverse elementen die voorhanden waren.

Voor mensen die Willem Witteveen gekend hebben, zullen de elementen die in De wet als kunstwerk worden samengevoegd ongetwijfeld herkenbaar zijn. Het boek brengt tal van thema's samen die Witteveen bezighielden: zijn kritiek op juridisch instrumentalisme, zijn pleidooi voor communicatieve wetgeving en republikeins burgerschap, zijn aandacht voor retorica, voor de symbolische en metaforische dimensie van het recht; zijn oproep tot een hernieuwde conceptualisering van rechtsstatelijkheid, tot een gerevitaliseerde en toegankelijke taal in het recht en de politiek, tot interactief, horizontaal bestuur, en tot slot zijn beschrijving van de politiek als theater en het recht als een zich ontwikkelende 'maatschappelijke betekenisconstructie'. Veel van dit materiaal is georganiseerd in de tien geboden voor wetgeving die hij in het middendeel van het boek beschrijft.

Deze tien geboden worden besproken tegen de achtergrond van een 'groot verhaal' over de ontwikkeling van de democratische rechtsstaat aan het eind van de $20^{\text {ste }}$ en het begin van de $21^{\text {ste }}$ eeuw, dat deels impliciet blijft maar dat evengoed het raamwerk vormt waarin al deze elementen een logische plaats hebben. Beginpunt van dit verhaal is de crisisanalyse van de democratische rechtsstaat van zijn 
promotor Herman van Gunsteren uit de jaren zeventig. In The Quest for Control (1976) had Van Gunsteren uiteengezet hoe de centralistische, top-down sturing van de samenleving in de opgezwollen sociale welvaartstaten van de jaren zestig en zeventig disfunctioneel was geworden. Deze centrale sturing verdrukte de democratische besluitvorming met technocratische beleidsoplossingen, bedacht door een naar binnen gekeerde coterie van deskundigen voor wie het recht bovenal een beleidsinstrument was om problemen op te lossen. Dit instrumentalisme stond niet alleen op gespannen voet met democratisch zelfbestuur, het liep ook vast in de weerbarstige complexiteit van de sociale realiteit. Overal leidden technocratische oplossingen tot 'unintended consequences'. De samenleving was simpelweg te complex en te veranderlijk geworden om nog vanuit de cockpit van de overheid te kunnen worden aangestuurd. Dit vroeg om meer interactie met betrokken partijen en de ontwikkeling van beleid in samenspraak met de mensen in het veld, een respons waarvoor Witteveen aanknopingspunten vond in het (neo-)Republikeinse ideaal van de autonome burger die zichzelf de wet stelt; een normatief ideaal van autonome burgers die hun steentje bijdragen aan de totstandkoming van het beleid en de wetgeving die hen aangaat.

Voor deze oplossing is in Nederland natuurlijk maar zeer beperkt gekozen in de afgelopen decennia. (En waar democratisch overleg werd ingevoerd, ontaardde het vaak in een bureacratische procedure.) Eind $20^{\text {ste }}$ en begin $21^{\text {ste }}$ eeuw werd niet publieke deliberatie, maar de onzichtbare hand van de markt de oplossing voor de aansturing van de steeds complexere samenleving. Deze omarming van de markt - door Witteveen in het boek besproken onder de noemer 'neoliberalisme' - heeft weer zijn eigen problemen, zijn eigen 'unintended consequences', opgeroepen. De vrijheid die het neoliberalisme belooft, is volgens Witteveen omgeslagen in het tegendeel:

Het neoliberalisme heeft een uitgesproken voorkeur voor de markt, of marktachtige instituties, boven de staat. De tucht van de markt neemt de plaats in van een sociaal contract dat berust op de reciprociteit tussen overheid en burgers. Georganiseerd wantrouwen is daarbij het leidende beginsel. Het neoliberalisme leidt tot verregaande ingrepen en omvattende controle, waardoor op den duur een surveillancestaat ontstaat (p. 37-8).

Veel van de besprekingen van eigentijdse wetsvoorstellen, praktijkvoorbeelden die Witteveen veelal ontleende aan zijn werkzaamheden in de Eerste Kamer, moeten in de sleutel worden gezien van dit grote verhaal, van deze ontwikkeling van het dirigisme van de oude welvaartstaat, via de marktwerking, naar de controle en het wantrouwen van de surveillancestaat.

Maar De wet als kunstwerk is meer dan alleen een analyse van de malaise van de sociale rechtsstaat. In De wet als kunstwerk is Witteveens aandacht voor de politiek-filosofische en rechtstheoretische traditie alom tegenwoordig. Hij bespreekt een scala aan klassieke argumenten uit de geschiedenis van de politieke filosofie en de rechtstheorie, niet als historische curiosa maar als relevante analyses die 
ons ook nu nog iets kunnen leren over wet en wetgeving. Dat zijn steeds goed geïnformeerde uitweidingen over centrale kwesties die in de rechtsfilosofische traditie een rol hebben gespeeld.

Aan het begin van Deel III reflecteert Witteveen op zijn gebruik van deze teksten uit de traditie. Volgens Witteveen moeten ze uiteraard begrepen worden tegen de achtergrond van de historische maatschappelijke en culturele context waarin ze zijn ontstaan. Maar het gaat hem niet om een puur antiquarische aandacht voor oude teksten louter gericht op historische documentatie, noch wil hij met zijn uitweidingen laten zien hoe gaandeweg misvattingen en malle ideeën zijn verlaten en onze eigen tijd zo verlicht is geworden. De overgeleverde teksten uit de rechtsfilosofische traditie zijn geen voorbije stations, geen waandenkbeelden uit een minder verlichte tijd, maar alternatieve perspectieven, bronnen waarmee je uit de vanzelfsprekende betekenis van onze huidige concepties kan breken:

Een klassieke tekst is een tekst die telkens weer wordt vertaald, in andere omstandigheden en voor een nieuw publiek. Het is de lezer die de tekst tot leven wekt, in het vermoeden dat daar iets te vinden is wat op geen andere manier toegankelijk is. [...] Wat de lezer die zich de tekst eigen maakt aan vertaling uitvoert, met alle transformatie van betekenis, is een handeling die de tekst tegelijk op afstand plaatst (het is verwerkt verleden geworden), maar ook dichterbij brengt (iets in de klassieke tekst vindt wel degelijk nog weerklank) (p. 415).

Het sluit in die zin misschien meer aan bij het laterale denken van Edward de Bono en zijn technieken om uit gebaande denkpaden te breken, een denker die Witteveen in hoofdstuk 17 bespreekt, dan bij een zoektocht naar historische nauwkeurigheid en de meest accurate interpretatie van wat een klassieke auteur voor ogen had.

Dit brengt ons weer terug naar het idee van De wet als kunstwerk. De notie van de wet die uit Witteveens boek naar voren komt, is die van een sociaal en cultureel artefact. Dat roept de vraag op hoe Witteveens eigen zijsprongetjes naar de poëzie en de beeldende kunst, zijn eigen blijken van lateraal denken in het boek, moeten worden geïnterpreteerd in relatie tot de wet. De eerste associatie die zijn gedicht en zijn afbeeldingen oproepen, zijn de Vijftigers en Cobra. Een van de miniaturen is getiteld: 'Op de berg van Lucebert'. Er is duidelijk een verwantschap in stijl: het loslaten van de traditionele vormvoorschriften van de poëzie, het gebruik van paradoxen, de naïeve stijl van de afbeeldingen, en de voorliefde voor handschrift (Witteveens handgeschreven onderschriften zijn misschien wel het meest ontroerende aspect van zijn miniaturen). Het project van de Vijftigers en Cobra na de Tweede Wereloorlog was om opnieuw te beginnen. De Vijftigers wilden breken met wat Lucebert de 'de veel te schone poëzieschool' van voor de Oorlog noemde, met zijn gekunstelde vorm en verheven taal. Cobra wilde terug naar de eerlijkheid van kindertekeningen en primitieve kunst. De verfijning en esthetiek van de poëzie en de beeldende kunst waren verdacht geworden door de gruwelen van het 
begin van de $20^{\text {ste }}$ eeuw. De vijftigers zochten naar een nieuwe vitaliteit en echtheid.

De parallel die zich opdringt, is die van de wetten als een systeem dat zijn oorspronkelijkheid heeft verloren. Wetgeving die te bureaucratisch is geworden, die verworden is tot een instrument van de technocratie, die te ver afstaat van de burgers, en die in toenemende mate voortkomt uit wantrouwen. Ook Witteveens project is in zekere zin bedoeld om de wetten nieuwe vitaliteit te geven, om van de wet weer een bezield kunstwerk te maken dat verbonden is met de leefwereld van de burgers. Dat is een project dat aandacht verdient. Verloop van Jaren (2015), de meest recente dichtbundel van de laatste Vijftiger, Remco Campert, eindigt met de strofen:

Horen en zien zullen me vergaan

als de rukwind van de dood

me van mijn adem berooft

En mijn woorden?

De wind zal ze meevoeren

en over de aarde verspreiden.

Laten we hopen dat de wind ook de woorden van Willem Witteveen zal meevoeren en nog lang rond zal laten gaan over Nederland. 